\title{
Increasing capacity to produce scenarios and models for biodiversity and ecosystem services
}

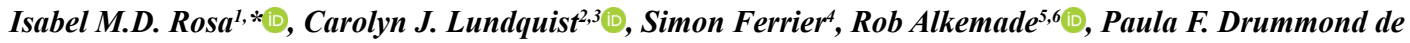

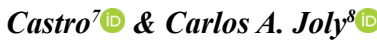 \\ ${ }^{1}$ Bangor University, School of Natural Sciences, Bangor, Gwynedd, Wales. \\ ${ }^{2}$ National Institute of Water and Atmospheric, Hamilton, New Zealand. \\ ${ }^{3}$ The University of Auckland, Auckland, New Zealand. \\ ${ }^{4}$ CSIRO Land and Water, Canberra, Australia. \\ ${ }^{5}$ PBL Netherlands Environmental Assessment Agency, Netherlands. \\ ${ }^{6}$ Environmental Systems Analysis group, Wageningen University and Research, The Netherlands \\ ${ }^{7}$ Universidade Estadual de Campinas, Laboratório de Estudos Avançados em Jornalismo Científico, Campinas, SP, Brazil. \\ ${ }^{8}$ Universidade Estadual de Campinas, Instituto de Biologia, Departamento de Biologia Vegetal, Campinas, SP, Brasil. \\ *Corresponding author: Isabel M.D. Rosa,e-mail: i.rosa@bangor.ac.uk \\ ROSA, I.M.D., LUNDQUIST, C.J., FERRIER, S., ALKEMADE, R., CASTRO, P.F.D., JOLY, C.A. Increasing \\ capacity to produce scenarios and models for biodiversity and ecosystem services. Biota Neotropica 20(suppl. 1): \\ e20201101. https://doi.org/10.1590/1676-0611-BN-2020-1101
}

\begin{abstract}
Extensive anthropogenic activities driven by the demand for agriculture and forestry products have led to dramatic reductions in biodiversity worldwide and significant changes in the provisioning of ecosystem services. These trends are expected to continue in the future as the world continues to develop without much consideration of the role that nature plays in sustaining human livelihoods. Scenarios and models can be important tools to help policy- and decision-makers foresee the impact of their decisions; thus, increasing capacity in creating such models and scenarios is of utmost importance. However, postgraduate training schools that focus on this topic are still rare. Here we present and reflect on the experience of the São Paulo School of Advanced Science on Scenarios and Modelling on Biodiversity and Ecosystem Services to Support Human Well-Being (SPSAS Scenarios). In addition, we introduce the Special Issue of Biota Neotropica that resulted from the activities taking place during the SPSAS Scenarios. In total, nine case studies emerged from the activities carried out during SPSAS Scenarios. These focused on a variety of ecosystems, their current drivers of change and expected trends, as well as on the development of alternative positive scenarios applying the recently developed Nature Futures Framework. We emphasize the need to increase capacity in scenario and modelling skills in order to address some of the existing gaps in producing policy-relevant scenarios and models for biodiversity and ecosystem services.
\end{abstract}

Keywords: Scenarios; Models; Biodiversity; Ecosystem Services; Nature Futures; IPBES.

\section{Capacitando profissionais para o desenvolvimento de cenários e modelos em biodiversidade e serviços ecossistêmicos}

Resumo: Atividades antropogênicas extensas, impulsionadas pela demanda por produtos da agricultura e da silvicultura, têm levado a reduções dramáticas na biodiversidade mundial e a mudanças significativas no provimento de serviços ecossistêmicos. Estas tendências devem continuar no futuro, pois o mundo continua a se desenvolver sem muita consideração pelo papel que a natureza desempenha em sustentar a subsistência humana. Cenários e modelos são ferramentas importantes para ajudar os tomadores de decisão a preverem o impacto de suas decisões, auxiliando na definição das melhores opções para políticas de conservação e uso sustentável; portanto o aumento da capacidade para o desenvolvimento de modelos e cenários é de suma importância. Entretanto, ainda são raros os cursos de pós-graduação que foquem na capacitação de profissionais para o desenvolvimento de modelos e cenários em biodiversidade e serviços ecossistêmicos. Neste trabalho apresentamos a experiência da Escola São Paulo de Ciências Avançadas de Cenários e Modelagem em Biodiversidade e Serviços Ecossistêmicos para Apoiar o BemEstar Humano (SPSAS Scenarios). Adicionalmente, apresentamos neste Número Especial da Biota Neotropica os resultados dos exercícios de modelagem e cenários desenvolvidos no decorrer da SPSAS Scenarios. No total, as atividades realizadas durante o SPSAS Scenarios resultaram em nove estudos de caso. Estes se concentraram em uma diversidade de ecossistemas, nos atuais drivers de mudança e as respectivas tendências, bem como nas 
Rosa, I.M.D. et al

alternativas de desenvolvimento visando cenários mais positivos propostos recentemente no contexto da Framework Futuros para Natureza da Plataforma Intergovernamental de Biodiversidade e Serviços Ecossistêmicos (IPBES). Enfatizamos aqui a necessidade de acelerar a capacitação de profissionais que trabalhem com cenários e modelagem de forma a preencher algumas lacunas existentes na produção de cenários e modelos relevantes para a tomada de decisão em biodiversidade e serviços ecossistêmicos

Palavras-chave: Cenários; Modelos; Biodiversidade; Serviços, Ecossistêmicos; Framework Futuros para Natureza; IPBES.

\section{Introduction}

The recent publication of the Global Assessment Report on Biodiversity and Ecosystem Services by the Intergovernmental Platform for Biodiversity and Ecosystem Services (Díaz et al. 2020) has once again put the spotlight on the extensive impacts that human activities are having on our planet as a whole. Most of these changes are a response to the demand for agriculture and forestry products. For instance, it has been estimated that the world has seen a 300\% increase in agricultural crop production since 1970, and about $45 \%$ increase in raw timber harvest (Díaz et al. 2020). This, however, comes at a high cost for the natural world. Alarmingly the assessment has also shown that biodiversity is declining at unprecedented rates, with an average loss of $20 \%$ of the abundance of native species since 1900 in most habitats, and nearly 1 million animal and plant species now threatened with extinction (Díaz et al. 2020). Moreover, these socio-economically driven activities have contributed to climate change. Work led by the Intergovernmental Panel for Climate Change (IPCC) has been crucial in highlighting how anthropogenic activities are impacting, and will continue to impact, the Earth's climate (IPCC 2019). It has been estimated that greenhouse gas (GHG) emissions have doubled since 1980, and the average temperature has risen by 0.7 degrees Celsius. Both the IPCC and IPBES emphasize that transformative change in the way the world is expected to develop is crucial to curb these trends and ensure we move towards a more sustainable future (Díaz et al. 2020). The recent and ongoing COVID-19 pandemic has also helped understand the potential consequences for human well-being of continuing to develop as in the past.

In this regard, scenarios and models can play an important role in supporting decision- and policy-makers in envisioning different futures under alternative pathways (or assumptions) (IPBES 2016). These have long been used at multiple scales in supporting environmental assessments (Nicholson et al. 2019), but seem to have largely failed in steering decision- and policy-makers into developing strategies and mechanisms that can lead towards sustainable futures (IPBES 2016). Developing such scenarios and models requires an interdisciplinary view and an understanding of what drives change (both directly and indirectly), the policy levers and mechanisms that might impact such change and the dimensions/aspects of biodiversity and ecosystem services that might be impacted by it (Rosa et al. 2020). Importantly, scenario exercises to date have involved limited consideration of the fundamental role that nature plays in human societies worldwide (Cardinale et al. 2016) and of the importance of adopting a pluralistic perspective on human-nature interactions (Rosa et al. 2017).

Capacity building is a crucial requirement for the development of robust scenario analysis and modelling. However, despite the growing production and use of scenarios and models by scientists, policy-makers and practitioners from across disciplines, postgraduate training courses on biodiversity and ecosystem services scenarios and models are still rare.
This paper has thus two main objectives: (1) to describe and reflect on the São Paulo School of Advanced Science on Scenarios and Modelling on Biodiversity and Ecosystem Services to Support Human Well-Being (SPSAS Scenarios); and (2) introduce this Special Issue of Biota Neotropica that was an outcome of the SPSAS Scenarios with nine papers emerging from the case studies developed and elaborated by the students during this capacity-building training course.

\section{The Summer School}

The São Paulo School of Advanced Science on Scenarios and Modelling on Biodiversity and Ecosystem Services to Support Human Well-Being (SPSAS Scenarios) took place in the city of São Pedro (about $150 \mathrm{~km}$ from São Paulo, Brazil) from the $1^{\text {st }}$ to $14^{\text {th }}$ of July 2019. Eighty-five participants from 21 nationalities and five continents - selected after a very competitive process, $4: 1$ - were immersed in this residential training course which took place over approximately 90 contact hours. In accordance with the course proposal, participants and speakers were hosted in a hotel. This venue provided not only space for the meetings, but also for ice-breaker activities and extensive opportunities for interactions among participants, during meals, in the swimming pool, at the bar and in the social gatherings organized as part of the course.

Participants were predominantly female (64\%). Most of them (79\%) were PhD students and the remaining $21 \%$ had completed their $\mathrm{PhD}$ between 2017 and 2019. Among the participants, five were public servants or from multilateral organizations, and were selected with the aim of not only training them to use new tools and approaches, but also to bring to the discussion real challenges experienced by decision-makers. Participants were from a wide range of backgrounds (Figure 1).

The topics covered by SPSAS Scenarios were divided in four main modules:

1. Ecosystem Services and Nature's Contribution to People: the evolution of, and current debate around, these concepts, was presented and discussed.

2. Challenges in the Development of Scenarios and Models focusing on direct and indirect drivers in biodiversity and ecosystem services, as well as the conceptual bases of scenarios and models.

3. IPBES Assessment on Scenarios and Modeling where the main authors of this technical assessment presented and discussed their findings.

4. Scenarios and Modeling to Achieve Brazil's Nationally Determined Contribution (NDC) in which some of the experts involved in establishing the Brazilian proposal to the Paris Climate Agreement presented and discussed how those goals were established. 


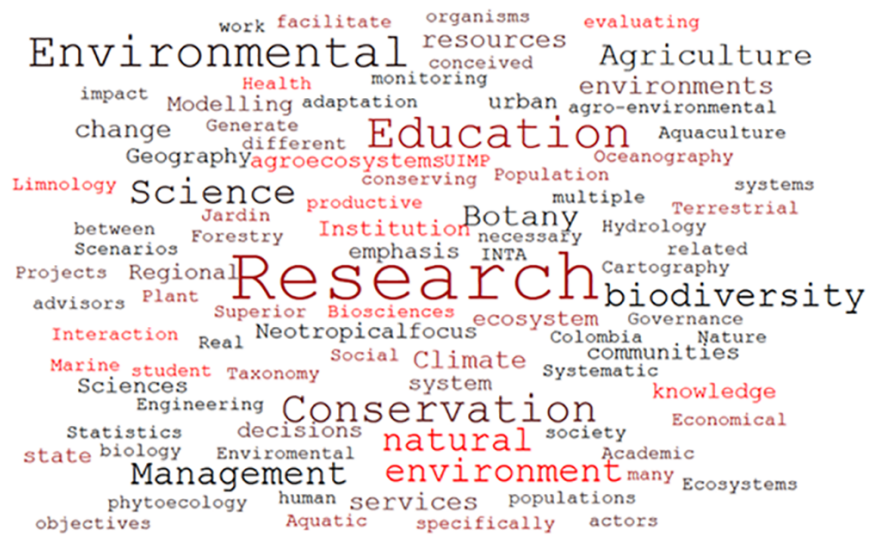

Figure 1. Word cloud of the diversity of professional training and background of participants, based on the frequency of the appearance of words in the item of the registration form requesting this information.

After a general introduction to biodiversity and ecosystem services (Module 1), from Module 2 onwards the students were divided into nine groups for a series of exercises entitled "real experience of modelling and scenarios". The topic of each group was suggested by the students themselves, further refined after a joint evaluation with the speakers. Each group then followed an organic process to develop their own case study alongside, and informed by, the lectures on the topics for the remainder of the SPSAS Scenarios. Their initial proposal for the case study was gradually refined in greater detail with the incorporation of new "layers" of knowledge from the speakers' presentations. First students were asked to articulate the question(s) to be addressed in the case studies, and then they started building a conceptual model that described the key components of the systems that were being studied. Second, the relationships between these key components were described and the monetary and non-monetary values of each component were discussed, first within the group, and then with all other participants for feedback. Direct and indirect drivers affecting biodiversity, ecosystem services and valuation were then addressed. Third, the students were incentivised to review existing policies that might impact their case studies, indicators they could use to track progress towards policy goals, and to use their creativity to think about alternative scenarios that could lead towards more positive futures. Finally, following this step, the students began to use existing data and tools, where possible, to model the impact of conservation policies on the drivers, and potential outcomes of their envisioned scenarios.

This organic way in which the groups developed their case studies was made possible by the availability of speakers to stay in São Pedro for a longer period than that provided exclusively for theoretical classes. In this way the speakers could follow the maturation of each case study, contributing whenever necessary to the work of the groups. The groups could schedule tutorials with the speakers in order to derive maximum benefit from their knowledge and experience. During the final presentation of the case studies the organizing committee of SPSAS Scenarios, lecturers and students decided to further develop each study and submit it for publication in this Special Issue of Biota Neotropica.

On the final day of the SPSAS Scenarios participants took some time to answer a set of questions focused on the positive and negative aspects of the School. Here are some of the comments submitted, showing that for most participants it was a valuable experience:
"I found the activities really innovative and interesting. It is important to recognize that in problem-solving situations comprising different interests there will always be conflicts and it is necessary for scientists to learn how to argue and defend our position in these situations, but also take into account the demands and needs of other sectors"; "Working in a case study with an interdisciplinary group was a real challenge and opportunity at the same time. We all learned a lot from each other's background and perspective. Overall, it was a great and enriching experience to work with the development of conceptual models."; "This course was a great opportunity to see how science and policy are connected. Given this experience, now I want to adapt my research and make it more suitable for policy makers, etc."; and "The school provided an outstanding opportunity to improve my postdoctoral proposal, especially providing inputs to increase the scale and impact of my research. I believe applying the IPBES framework will be very important in the next few years and the School provided an excellent guide to do that".

\section{The Special Issue}

The study cases developed during SPSAS Scenarios became the nine papers of this Special Issue and are listed below:

1. Drivers of change in biodiversity and ecosystem services in the Cantareira System Protected Area: a prospective analysis of the implementation of public policies (Dib et al., this issue).

2. Pathways to positive scenarios for the Amazon forest in Pará state, Brazil (Siqueira-Gay et al., this issue).

3. Urban expansion in the Atlantic Forest: applying the Nature Futures Framework to develop a conceptual model and future scenarios (Lembi et al., this issue).

4. A conceptual model to understand the drivers of change in tropical wetlands: a comparative assessment in India and Brazil (Sarkar et al., this issue).

5. A conceptual model to assess the impact of anthropogenic drivers on water-related ecosystem services in the Brazilian Cerrado (Resende et al., this issue).

6. Future scenarios of land-use-cover effects on pollination supply and demand in São Paulo State, Brazil (Barbosa et al., this issue)

7. Insights for policy-based conservation strategies for the Rio de la Plata Grasslands through IPBES framework (Gorosabel et al., this issue)

8. Development of a conceptual framework for the management of biodiversity and ecosystem services in the Mexican Caribbean (Sanchez-Quinto et al., this issue)

9. Scenario-modelling for the sustainable management of non-timber forest products in tropical regions (Bondé et al., this issue).

All nine studies addressed cases where increasing human pressure affects biodiversity and some vital ecosystem services, in a variety of different ecosystems. Human pressure often results from changing land use, such as in Siqueira-Gay et al., Lembi et al. and Barbosa et al., but also from increasing direct use of species (e.g. Shea trees) or pollution (Sarkar et al.). The aims of the various case studies were in general terms similar as they all focused on understanding the drivers of changes in biodiversity or ecosystem services and on developing pathways to shift current (negative) trends. 
For example: "Thus, we aim at providing an understanding of the drivers of forest cover change in Pará state by applying the IPBES framework for proposing ways to shift current trends towards positive scenarios" (Siqueira-Gay et al. 2020) and "..., there is an urgent need to identify and understand the interactions between various drivers of change triggering wetland degradation and mantaining their ecological character for perpetual delivery of ecosystem services" (Sarkar et al. 2020).

The papers emerging from this exercise at SPSAS Scenarios highlighted the breadth of topics that can be covered by scenarios and models of biodiversity and ecosystem services (Table 1). While most case studies were focused within Latin America and the Caribbean, the background and experiences of the participants resulted in one case study of sub-Saharan Africa, and one further case study involving a comparison of India and Brazil (Table 1). Moreover, case studies covered a diversity of ecosystems, including marine, aquatic, terrestrial and urban ecosystems. Within these broader categories, coastal ecosystem elements included mangroves and coral reefs, and terrestrial ecosystems including a diversity of habitats from tropical forest to savannahs, and grasslands to croplands (Table 1).

As briefly described above, once the research question was defined, the development of a model - i.e. a qualitative or quantitative description of key components of a system and of relationships between those components - began with a solid conceptual framework (Guisan \& Zimmerman, 2000; IPBES, 2016) representing the understanding of that system. At first, the cases were formulated very broadly, thus the urge to formulate a conceptual model of the (eco)system central to the case studies helped the students to focus on the main issues (and the main components of the system that impact that issue), avoiding them getting lost in details. In particular, first, the key components were defined (Table 1) including the link between these key components, which was often represented visually by boxes with connecting arrows (Jackson et al., 2000). Key components varied greatly between case studies, such as water quality and quantity determining water health (Sarkar et al., 2020); forest cover change determined by urban expansion (Siqueira-Gay et al., 2020); and Shea tree cover and its harvest (Bondé et al., 2020). These key components provided the foundation on which to further build the complete conceptual model, as many influencing factors often play a role in determining changes in the key components.
Challenges remained in delineating the system that is considered in the case studies, by defining boundary elements, and in keeping the conceptual model as parsimonious as possible, which required an iterative process of discussions within the modelling team (and more broadly with the other participants and teachers), consulting experts and reviewing literature (Jackson et al. 2000). In all case studies the conceptual modelling involved the formulation of a (semi-)quantitative model, enabling the evaluation of multiple scenarios.

The models represented in the nine case studies highlighted some of the most common drivers of biodiversity and ecosystem services. For instance, IPBES has identified (1) changes in land and sea use; (2) direct exploitation of organisms; (3) climate change; (4) pollution and (5) invasive alien species (Díaz et al., 2020) as the five most important direct drivers of change. These were commonly included in the case studies, such as for example in Siqueira-Gay et al. (2020), where the socio-ecological system of forest cover change in the Amazon was investigated; or in Barbosa et al. (2020) when evaluating pollination service changes in Brazil; or even in Estigarribia et al. (2020) when analysing changes in biodiversity in the grasslands of South America. Additionally, indirect drivers commonly identified independently of the geographic location of the case study were population pressure, economic growth and international demand, governance, and policy changes, such as for example in the case of Dib et al. (2020) for the Cantareira system in Brazil; or in Sarkar et al. (2020) for the wetlands of Brazil and India; or in Lembi et al. (2020) when analysing urban expansion in the Atlantic Forest; and in Bondé et al. (2020) for the shea trees in West Africa.

To monitor changes in these drivers, and their consequent impacts on the focal component of the case study, several indicators have been identified and proposed within the case studies. Some of the more commonly proposed indicators were (1) the extent of land use change (e.g. urban expansion in Lembi et al. [2020], forest cover change in Siqueira-Gay et al. [2020], or wetland extension in Sarkar et al. [2020]); (2) biodiversity change, assessed either as the number of species or local species richness (e.g., Siqueira-Gay et al. [2020]) or as the mean species abundance (e.g. Sanchez-Quinto et al. [2020]); and (3) ecosystem services change, such as was the case in Sanchez-Quinto et al. (2020) for a variety of provisioning, regulating, supporting and cultural services; and in Verde Selva et al. (2020) for water quality and quantity.

Table 1. Geographic, ecosystem and thematic focus of the papers in the Special Issue

\begin{tabular}{llll}
\hline \multicolumn{1}{c}{ Paper } & \multicolumn{1}{c}{ Country(ies) } & \multicolumn{1}{c}{ Ecosystem } & \multicolumn{1}{c}{ Focal point } \\
\hline Sarkar et al. & India and Brazil & Wetlands & Wetland Health (water quality and quantity) \\
Siqueira-Gay et al. & Brazil & Amazon forest & Forest Cover Change (deforestation) \\
Verde Selva et al. & Brazil & Cerrado (savannah) & Water quality and quantity \\
Dib et al. & Brazil & Cantareira system & Biodiversity (MSA), Sediment loss, Soil loss and \\
& & (protected area) & Forest Cover Change \\
Lembi et al. & Brazil & Urban areas & Urban expansion \\
Barbosa et al. & Brazil & Croplands & Pollination and Crop production \\
Sanchez-Quinto et al. & Mexican Caribbean & Coastal and Marine & Biodiversity (Mangrove and Coral Reef MSA) \\
Estigarribia et al. & Rio de la Plata (Argentina, Uruguay and Brazil) & Grasslands & Biodiversity and Ecosystem function \\
Bondé al. & sub-Saharan Africa & Shea trees & Tree cover \\
\hline
\end{tabular}


Identifying the drivers and the indicators is a crucial step to then think about scenarios (and associated assumptions) creatively that can drive the system towards more positive trends. In some cases, the groups were able to use existing tools and data to derive quantitative estimates of changes in their focal components as a result of their envisioned scenarios. For instance, Sanchez-Quinto et al. (2020) used GLOBIO3 (Alkemade et al. 2009) to project changes in the mean species abundance of mangroves and proposed a modification to suit the analysis for coral reefs as well. Barbosa et al. (2020) used the OTIMIZAGRO model (Soares-Filho et al., 2013) in combination with an ecosystem services matrix approach (Burkhard et al., 2009) to estimate changes in pollination services. Dib et al. (2020) used InVEST 3.7.0 (Hamel et al. 2015) to determine changes in the Sediment Delivery Ratio (SDR).

An important advancement in global biodiversity scenarios, catalysed by the IPBES Scenarios and Models Expert Group, is the development of the Nature Futures Framework (NFF) (Pereira et al. in press). SPSAS Scenarios provided the opportunity to introduce this novel scenarios framework to the next generation of biodiversity scenario experts, and to determine if it could be applied across a diversity of case studies, primarily reflecting nature and nature's contributions to people in the global south.

The NFF emerged from a future visioning exercise with a diverse group of stakeholders from around the world, where multiple knowledge systems were brought together to imagine what the future could be for nature and nature's contributions to people (Lundquist et al., 2017; Pereira et al., in press). The NFF is underpinned by the multitude of ways that humans value, experience and perceive nature and the benefits that it provides to society (Díaz et al., 2015; O’Neill et al., 2008). The NFF can be associated with three broad suites of values which people place on nature: intrinsic, instrumental and relational (Pascual et al., 2017). In "Nature for Nature" people value nature for its intrinsic and existence values, and the preservation of nature's diversity and functions is of primary importance. In "Nature for Society" nature is viewed as a provider of direct and indirect benefits to society, where humans benefit from the instrumental values that nature provides. Finally, "Nature as Culture" views humans as an integral part of natural systems, where societies, cultures, traditions and faiths are intricately intertwined with nature, and relational values such as those that reflect cultural identities, mental health and ways of life are dominant (Schoolenberg et al., 2018). This concept of people living in harmony with nature is not exclusive to indigenous worldviews, for example, the wider movement to help urban and rural communities to reconnect with nature to optimize the benefits of nature for mental health and human well-being (Chan et al., 2016).

At SPSAS Scenarios, students were asked to consider how future scenarios would differ for their particular case study if the imagined future was designed to maximise a particular NFF value perspective (Nature for Nature, Nature for Society, or Nature as Culture). Students discussed how the direct and indirect drivers in their case study influenced each of the value perspectives, which policy or management interventions could be used to maximise the nature perspectives, and which biological, ecological, cultural and socioeconomic indicators could be used to assess 'success' for each nature perspective.
Two of the perspectives were typically easy for students to envision: Nature for Nature, reflecting common goals of conservation movements, the use of management tools such as protected areas, and biodiversity indicators such as species richness and threatened species; and Nature for Society, with many conceptual models focussed around the production of food, wood or other natural resources, water regulation, or carbon sequestration. In contrast, the concept of Nature as Culture provided for diverse discussions; many case studies had indigenous communities as integral components of their conceptual model, allowing them to envision how indicators of success for this nature perspective were often quite different from many of the typical metrics utilised by biodiversity scenarios. Several of the papers in the Special Issue make use of the NFF, such as for example Dib et al. (2020), Lembi et al. (2020), Sarkar et al. (2020), Siqueira-Gay et al. (2020), and Verde-Selva et al. (2020), thus illustrating its flexibility to be applied to multiple ecosystems at a variety of spatial scales.

\section{Conclusions}

As the world still struggles to handle the ongoing COVID-19 pandemic, it has become ever more important to inspire transformative changes to our current lifestyles, and to steer policy- and decisionmakers towards envisioning a future for our planet that can be both sustainable and economically prosperous. Current scenarios, however, still fail to do so (Rosa et al., 2020), but the emergence of the NFF (Pereira et al., in press) is a positive shift towards a more inclusive and pluralistic approach to scenario development. This is a crucial first step that can be then followed by implementation of qualitative and quantitative approaches that aim to translate such scenarios into projections of impacts on biodiversity, ecosystem services, and ultimately human well-being. With the experience of SPSAS Scenarios and the variety of case studies addressed in the resulting Special Issue, we have shown the potential of increasing capacity in scenario and modeling training, and the flexibility that the NFF offers to address quite distinct case studies. It is our hope that with this kind of training activity, and the widespread adoption of the NFF, the knowledge and critical thinking of positive scenario development can be spread across institutions. This can, in turn, lead to innovative modeling approaches, thereby collectively helping to deliver transformative changes and more evidence-based policy- and decision-making.

\section{Acknowledgements}

We thank of the São Paulo Research Foundation/FAPESP for the sponsoring São Paulo School of Advanced Science on Scenarios and Modelling on Biodiversity and Ecosystem Services to Support Human Well-Being (SPSAS Scenarios) through the BIOTA/FAPESP Program (Process 2018/16445-5).

Thanks are also due to the Institute of Biology of the University of Campinas for including the SPSAS Scenarios as a discipline of the Graduate Program in Ecology and for the accountability support given by Mrs. Ligiane Marinho de Ávila, SAIP-IB, and to the Inter-American Institute for Global Change Research/IAI for helping to plan and advertise the SPSAS Scenarios through its network, increasing its visibility. 
We also thank the staff of the Hotel Fonte Colina Verde of São Pedro for providing excellent logistics for the realization of the SPSAS Scenarios.

Last but not least, we are grateful to Alice Ramos de Moraes, Rafael Flora Ramos, Rafael Cavalcanti Lembi, Gabriela Brasci Berro, Maíra de Campos Gorgulho Padgurschi and Melina Sampaio, most of them graduate students from the University of Campinas, who helped on the organization of SPSAS Scenarios and gave fantastic support during the School, promoting integration activities to all participants, as well as working as tutors of the group.

\section{Authors' Contributions}

Isabel M.D. Rosa: contribution to the concept and design of the SPSAS Scenarios; substantial contribution to manuscript preparation adding intellectual content; contribution to critical revision

Carolyn J. Lundquist: contribution to the concept and design of the SPSAS Scenarios; contribution to critical revision, adding intellectual content; contribution to critical revision

Simon Ferrier: contribution to the concept and design of the SPSAS Scenarios; contribution to critical revision, adding intellectual content; contribution to critical revision

Rob Alkemade: contribution to the concept and design of the SPSAS Scenarios; contribution to critical revision, adding intellectual content; contribution to critical revision

Paula F. Drummond de Castro: substantial contribution to the concept, organization and design of the SPSAS Scenarios; contribution to manuscript preparation adding intellectual content; contribution to critical revision

Carlos A. Joly: substantial contribution to the concept, organization and design of the SPSAS Scenarios; contribution to manuscript preparation adding intellectual content; contribution to critical revision

\section{Conflicts of Interest}

The authors declare that they have no conflict of interest related to the publication of this manuscript.

\section{References}

ALKEMADE, R., VAN OORSCHOT, M., MILES, L., NELLEMANN, C., BAKKENES, M. \& TEN BRINK, B., 2009. GLOBIO3: a framework to investigate options for reducing global terrestrial biodiversity loss. Ecosystems (12), 374-390

BARBOSA, M.M., CARNEIRO, L.T., PEREIRA, M.F.C.S., RODRIGUEZ, C.Z., CHAGAS, T.R.F., MOYA, W., BERGAMINI, L.L., MANCINI, M.C.S., PAES, N.D. \& GIRALDO, L.C.P. 2020. Future scenarios of land-use-cover effects on pollination supply and demand in São Paulo State, Brazil. Biota Neotropica, 20(Suppl. 1), e20190906. https://doi. org/10.1590/1676-0611-bn-2019-0906

BONDÉ, L.; ASSIS, J. C.; GORDILLO, S.B.; CANALES-GOMEZ, E.; FAJARDO, J.; MARRÓN-BECERRA, A.; NOGUERA-URBANO, E.; WEIDLICH, E. \& AMENT, J. 2020. Scenario-modelling for the sustainable management of non-timber forest products in tropical regions. Biota Neotropica, 20(Suppl. 1) http://dx.doi.org/10.1590/1676-0611-bn-2019-0898

CARDINALE, B.J., DUFFY, J.E., GONZALEZ, A., HOOPER, D.U., PERRINGS, C., VENAIL, P., NARWANI, A., MACE, G.M., TILMAN, D., WARDLE, D.A. AND KINZIG, A.P. 2012. Biodiversity loss and its impact on humanity. Nature, 486(7401), 59-67.
CHAN, K. M. A., P BALVANERA, K. BENESSAIAH, M. CHAPMAN, S. DÍAZ, E. GÓMEZ-BAGGETHUN, R. GOULD, N. HANNAHS, K. JAX, S. KLAIN, G. W. LUCK, B. MARTÍN-LÓPEZ, B. MURACA, B. NORTON, K. OTT, U. PASCUAL, T. SATTERFIELD, M. TADAKI, J. TAGGART, AND N. TURNER. 2016. Why protect nature? Rethinking values and the environment. Proceedings of the National Academy of Sciences 113:1462-1465.

DÍAZ, S., S. DEMISSEW, J. CARABIAS, C. JOLY, M. LONSDALE, N. ASH, A. LARIGAUDERIE, J. R. ADHIKARI, S. ARICO, A. BÁLDI, A. BARTUSKA, I. A. BASTE, A. BILGIN, E. BRONDIZIO, K. M. A. CHAN, V. E. FIGUEROA, A. DURAIAPPAH, M. FISCHER, R. HILL, T. KOETZ, P. LEADLEY, P. LYVER, G. M. MACE, B. MARTIN-LOPEZ, M. OKUMURA, D. PACHECO, U. PASCUAL, E. S. PÉREZ, B. REYERS, E. ROTH, O. SAITO, R. J. SCHOLES, N. SHARMA, H. TALLIS, R. THAMAN, R. WATSON, T. YAHARA, Z. A. HAMID, C. AKOSIM, Y. AL-HAFEDH, R. ALLAHVERDIYEV, E. AMANKWAH, S. T. ASAH, Z. ASFAW, G. BARTUS, L. A. BROOKS, J. CAILLAUX, G. DALLE, D. DARNAEDI, A. DRIVER, G. ERPUL, P. ESCOBAR-EYZAGUIRRE, P. FAILLER, A. M. M. FOUDA, B. FU, H. GUNDIMEDA, S. HASHIMOTO, F. HOMER, S. LAVOREL, G. LICHTENSTEIN, W. A. MALA, W. MANDIVENYI, P. MATCZAK, C. MBIZVO, M. MEHRDADI, J. P. METZGER, J. B. MIKISSA, H. MOLLER, H. A. MOONEY, P. MUMBY, H. NAGENDRA, C. NESSHOVER, A. A. OTENG-YEBOAH, G. PATAKI, M. ROUE, J. RUBIS, M. SCHULTZ, P. SMITH, R. SUMAILA, K. TAKEUCHI, S. THOMAS, M. VERMA, Y. YEO-CHANG, AND D. ZLATANOVA. 2015. The IPBES Conceptual Framework - connecting nature and people. Current Opinion in Environmental Sustainability 14:1-16.

IPBES 2019. Summary for policymakers of the global assessment report on biodiversity and ecosystem services of the Intergovernmental Science-Policy Platform on Biodiversity and Ecosystem Services. S. Díaz, J. Settele, E. S. Brondízio E.S., H. T. Ngo, M. Guèze, J. Agard, A. Arneth, P. Balvanera, K. A. Brauman, S. H. M. Butchart, K. M. A. Chan, L. A. Garibaldi, K. Ichii, J. Liu, S. M. Subramanian, G. F. Midgley, P. Miloslavich, Z. Molnár, D. Obura, A. Pfaff, S. Polasky, A. Purvis, J. Razzaque, B. Reyers, R. Roy Chowdhury, Y. J. Shin, I. J. Visseren-Hamakers, K. J. Willis, and C. N. Zayas (eds.). IPBES secretariat, Bonn, Germany. 56 pages. https://doi.org/10.5281/zenodo.3553579

DIB, V., NALON, M.A., AMAZONAS, N.T., VIDAL, C.Y., ORTIZRODRÍGUEZ, I.A., DANĚK, J., OLIVEIRA, M.F., ALBERTI, P., SILVA, R.A., PRECINOTO, R.S. \& GOMES, T.F. 2020 Drivers of change in biodiversity and ecosystem services in the Cantareira System Protected Area: A prospective analysis of the implementation of public policies. Biota Neotropica, 20(Suppl. 1), e20190915. https://doi.org/10.1590/16760611-bn-2019-0915

GOROSÁBEL, A., ESTIGARRIBIA, L., LOPES, L.F., MARTINEZ, A.M., MARTÍNEZ-LANFRANCO, J.A., ADENLE, A.A., RIVERA-REBELLA, C., \& OYINLOLA, M.A. 2020. Insights for policy-based conservation strategies for the Rio de la Plata Grasslands through the IPBES framework. Biota Neotropica, 20(Suppl. 1), e20190902. https://doi.org/10.1590/16760611-bn-2019-0902

GUISAN, A. \& ZIMMERMANN, N.E. 2000. Predictive habitat distribution models in ecology. Ecological Modelling 135: 147-186.

HAMEL, P., CHAPLIN-KRAMER, R., SIM, S., \& MUELLER, C. 2015. A new approach to modeling the sediment retention service (InVEST 3.0): Case study of the Cape Fear catchment, North Carolina, USA. Science of the Total Environment (524), 166-177.

IPBES 2016. The methodological assessment report on scenarios and models of biodiversity and ecosystem services of the Intergovernmental SciencePolicy Platform on Biodiversity and Ecosystem Services. S. Ferrier, K. N. Ninan, P. Leadley, R. Alkemade, L. A. Acosta, H. R. Akçakaya, L. Brotons, W. W. L. Cheung, V. Christensen, K. A. Harhash, J. Kabubo-Mariara, C. Lundquist, M. Obersteiner, H. M. Pereira, G. Peterson,R. Pichs-Madruga, N. Ravindranath, C. Rondinini and B. A. Wintle (eds.). Secretariat of the Intergovernmental Science-Policy Platform on Biodiversity and Ecosystem Services, Bonn, Germany. 348 pages. Available at https://ipbes.net/ policy-support/assessments/methodological-assessment-scenarios-modelsbiodiversity-ecosystem 
IPCC, 2019. Climate Change and Land: an IPCC special report on climate change, desertification, land degradation, sustainable land management, food security, and greenhouse gas fluxes in terrestrial ecosystems. P.R. Shukla, J. Skea, E. Calvo Buendia, V. Masson-Delmotte, H.-O. Pörtner, D. C. Roberts, P. Zhai, R. Slade, S. Connors, R. van Diemen, M. Ferrat, E. Haughey, S. Luz, S. Neogi, M. Pathak, J. Petzold, J. Portugal Pereira, P. Vyas, E. Huntley, K. Kissick, M. Belkacemi, J. Malley, (eds.). Available at https://www.ipcc.ch/srccl/

JACKSON, L.J., TREBITZ, A.S. \& COTTINGHAM, K.L. 2000. An introduction to the Practice of Ecological Modeling BioScience 50(8), 694-706.

LEMBI, R.C., CRONEMBERGER, C., PICHARILLO, C., KOFFLER, S., SENA, P.H.A., FELAPPI, J.F., MORAES, A.R., ARSHAD, A., SANTOS, J.P., \& MANSUR, A.V. 2020. Urban expansion in the Atlantic Forest: applying the Nature Futures Framework to develop a conceptual model and future scenarios. Biota Neotropica, 20(Suppl. 1), e20190904. https:// doi.org/10.1590/1676-0611-bn-2019-0904

LUNDQUIST, C. J., H. M. PEREIRA, R. ALKEMADE, E. DEN BELDER, S. CARVALHO RIBEIRO, K. DAVIES, A. GREENAWAY, J. HAUCK, S. KARLSSON-VINKHUYZEN, H. KIM, N. KING, T. LAZAROVA, L. PEREIRA, G. PETERSON, F. RAVERA, T. VAN DEN BRINK, A. ARGUMEDO, C. ARIDA, D. ARMENTERAS, A. G. AUSSEIL, B. BAPTISTE, J. BELANGER, K. BINGHAM, A. BOWDEN-KERBY, M. CAO, J. CARINO, P. A. VAN DAMME, R. DEVIVO, F. DICKSON, J. P. DUSHIMUMUREMYI, S. FERRIER, A. FLORES-DÍAZ, M. FOLEY, J. GARCIA MARQUEZ, P. GIRALDO-PEREZ, S. GREENHAIGH, D. J. HAMILTON, P. HARDISON, G. HICKS, K. HUGHEY, R. KAHUIMCCONNELL, G. KARURI-SEBINA, M. DE KOCK, P. LEADLEY, F. LEMAITRE, E. MALTSEVA, C. A. DE MATTOS SCARAMUZZA, M. METWALLY, W. NELSON, H. NGO, C. NEUMANN, C. NORRIE, J. PERRY, R. QUINTANA, V. E. RODRIGUEZ OSUNA, C. ROEHRL, J. SEAGER, H. SHARPE, T. SHORTLAND, P. SHULBAEVA, U. R. SUMAILA, Y. TAKAHASHI, N. TITEUX, S. TIWARI, C. TRISOS, A. URSACHE, A. WHEATLEY, D. WILSON, S. WOOD, E. VAN WYK, T. X. YUE, D. ZULFIKAR, M. BRAKE, D. LEIGH, AND P. LINDGRENSTREICHER. 2017. Visions for nature and nature's contributions to people for the 21 st century. 123 pages. NIWA Science and Technology Series National Institute of Water \& Atmospheric Research Ltd., Wellington, New Zealand. Available at https://niwa.co.nz/sites/niwa.co.nz/files/IPBESNature-Futures-report_2017.pdf

NICHOLSON, E., FULTON, E.A., BROOKS, T.M., BLANCHARD, R., LEADLEY, P., METZGER, J.P., MOKANY, K., STEVENSON, S., WINTLE, B.A., WOOLLEY, S.N. \& BARNES, M. 2019. Scenarios and models to support global conservation targets. Trends in ecology \& evolution, 34(1), 57-68.

O'NEILL, J., HOLLAND, A. \& LIGHT, A. 2009. Environmental values. Routledge. Geographical Journal 175(1):90-92 https://doi.org/10.1111/ j.1475-4959.2009.318_9.x

PASCUAL, U., P. BALVANERA, S. DÍAZ, G. PATAKI, E. ROTH, M. STENSEKE, R. T. WATSON, E. BAŞAK DESSANE, M. ISLAR, E. KELEMEN, V. MARIS, M. QUAAS, S. M. SUBRAMANIAN, H. WITTMER, A. ADLAN, S. AHN, Y. S. AL-HAFEDH, E. AMANKWAH, S. T. ASAH, P. BERRY, A. BILGIN, S. J. BRESLOW, C. BULLOCK, D. CÁCERES, H. DALY-HASSEN, E. FIGUEROA, C. D. GOLDEN, E. GÓMEZ-BAGGETHUN, D. GONZÁLEZ-JIMÉNEZ, J. HOUDET, H. KEUNE, R. KUMAR, K. MA, P. H. MAY, A. MEAD, P. O'FARRELL, R. PANDIT, W. PENGUE, R. PICHIS-MADRUGA, F. POPA, S. PRESTON, D. PACHECO-BALANZA, H. SAARIKOSKI, B. B. STRASSBURG, M. VAN DEN BELT, M. VERMA, F. WICKSON, AND N. YAGI. 2017. Valuing nature's contributions to people: the IPBES approach. Current Opinion in Environmental Sustainability (26-27), 7-16.
PEREIRA, L., DAVIES, K. K., DEN BELDER, E., FERRIER, S., KARLSSONVINKHUYZEN, S., KIM, H., KUIPER, J. J., OKAYASU, S., PALOMO, M. G., PEREIRA, H. M., PETERSON, G., SATHYAPALAN, J., SCHOOLENBERG, M., ALKEMADE, R., CARVALHO RIBEIRO, S., GREENAWAY, A., HAUCK, J., KING, N., LAZAROVA, T., RAVERA, F., CHETTRI, N., CHEUNG, W. W. L.,HENDRIKS, R. J. J., KOLOMYTSEV, G., LEADLEY, P., METZGER, J. P., NINAN, K. N., PICHS, R., POPP, A., RONDININI, C., ROSA, I., VAN VUUREN, D., \& LUNDQUIST, C. J. (in press) Developing multi-scale and integrative nature-people scenarios using the Nature Futures Framework. People and Nature https://doi.org/10.1002/pan3.10146

RESENDE, F.D., DENMAN, L.A.C., SELVA, G.V., CAMPANHÃO, L.M.B., NOBRE, R.L.G., JIMENEZ, Y.G., LIMA, E.M. \& NIEMEYER, J. 2020. A conceptual model to assess the impact of anthropogenic drivers on waterrelated ecosystem services in the Brazilian Cerrado. Biota Neotropica, 20(Suppl. 1), e20190899. https://doi.org/10.1590/1676-0611-bn-2019-0899

ROSA, I. M. D., H. M. PEREIRA, S. FERRIER, R. ALKEMADE, L. A. ACOSTA, H. R. AKCAKAYA, E. DEN BELDER, A. M. FAZEL, S. FUJIMORI, M. HARFOOT, K. A. HARHASH, P. A. HARRISON, J. HAUCK, R. J. J. HENDRIKS, G. HERNÁNDEZ, W. JETZ, S. I. KARLSSON-VINKHUYZEN, H. KIM, N. KING, M. T. J. KOK, G. O. KOLOMYTSEV, T. LAZAROVA, P. LEADLEY, C. J. LUNDQUIST, J. GARCÍA MÁRQUEZ, C. MEYER, L. M. NAVARRO, C. NESSHÖVER, H. T. NGO, K. N. NINAN, M. G. PALOMO, L. M. PEREIRA, G. D. PETERSON, R. PICHS, A. POPP, A. PURVIS, F. RAVERA, C. RONDININI, J. SATHYAPALAN, A. M. SCHIPPER, R. SEPPELT, J. SETTELE, N. SITAS, AND D. VAN VUUREN. 2017. Multiscale scenarios for nature futures. Nature Ecology \& Evolution 1:1416-1419.

ROSA, ISABEL MD, ANDY PURVIS, ROB ALKEMADE, REBECCA CHAPLIN-KRAMER, SIMON FERRIER, CARLOS A. GUERRA, GEORGE HURTT ET AL. 2020. Challenges in producing policy-relevant global scenarios of biodiversity and ecosystem services. Global Ecology and Conservation 22 (2020): e00886.

SÁNCHEZ-QUINTO, A., COSTA, J.C., ZAMBONI, N.S., SANCHES, F.H.C., PRINCIPE, S.C., VIOTTO, E.V., CASAGRANDA, E., VEIGA-LIMA, F.A., POSSAMAI, B., \& FARONI-PEREZ, L. 2020. Development of a conceptual framework for the management of biodiversity and ecosystem services in the Mexican Caribbean. Biota Neotropica, 20(Suppl. 1), e20190901. https:// doi.org/10.1590/1676-0611-bn-2019-0901

SARKAR, P., SALAMI, M., GITHIORA, Y., VIEIRA, R., NAVARRO, A, CLAVIJO, D., \& PADGURSCHI, M. 2020. A conceptual model to understand the drivers of change in tropical wetlands: a comparative assessment in India and Brazil. Biota Neotropica, 20(Suppl. 1), e20190913. https://doi.org/10.1590/1676-0611-bn-2019-0913

SCHOOLENBERG, M., E. DEN BELDER, S. OKAYASU, R. ALKEMADE, C. LUNDQUIST, H. PEREIRA, N. CHETTRI, W. CHEUNG, S. FERRIER, J. HAUCK, R. J. J. HENDRIKS, S. I. KARLSSON-VINKHUYZEN, H. KIM, G. KOLOMYTSEV, J. KUIPER, P. LEADLEY, J. P. METZGER, K. N. NINAN, G. PALOMO, L. PEREIRA, R. PICHS, A. POPP, F. RAVERA, C. RONDININI, I. ROSA, J. SATHYAPALAN, AND D. VAN VUUREN. 2018. Report on the Workshop 'Next Steps in Developing Nature Futures'. PBL Netherlands Environmental Assessment Agency, The Hague, The Netherlands.

SIQUEIRA-GAY, J., YANAI, A.M., LESSMANN, J., PESSÔA, A.C.M., BORJA, D., CANOVA, M., \& BORGES, R.C. 2020. Pathways to positive scenarios for the Amazon forest in Pará state, Brazil. Biota Neotropica, 20(Suppl. 1), e20190905. https://doi.org/10.1590/1676-0611-bn-2019-0905

SOARES-FILHO, B.S. 2013. "OTIMIZAGRO: Uma Plataforma Integrada de Modelagem de Uso e Mudanças no Uso da Terra para o Brasil.” Final report.

Received: 03/08/2020 Revised: $20 / 08 / 2020$ Accepted: 20/08/2020

Published online: 14/09/2020 